eficial to each individual and thus enhances the impact of the internationalization of Japanese higher education.

\section{Consolidating ERASMUS Mobility in Spain During the Economic Crisis}

\section{Adriana Pérez Encinas}

Adriana Pérez Encinas is assistant lecturer and researcher in higher education at the Faculty of Business and Economics, Universidad Autónoma de Madrid, Spain. E-mail: adriana.perez.encinas@uam.es.

$\mathrm{T}$ he ERASMUS+ program of the European Commission, which is funded during the period 20I4-2020 and includes education and training as well as youth and sport activities, is motivating thousands of European students to undertake part of their studies abroad. It has received a significant budget increase-40 percent more, in fact-over what was allocated for the previous ERASMUS program, which over the past 25 years has enabled more than 3 million students to study abroad as part of their home degree. The crisis in Spain is leading thousands of university students to decide to carve out a better future for themselves by carrying out internships, part of their studies, their whole degree in other European countries, or even on other continents. Despite the fact that the length of the ERASMUS grant has been reduced to one semester and that many families cannot easily afford this economic burden, ERASMUS mobility is being consolidated as part of the Spanish university curriculum.

\section{ERASMUS Mobility WITHIN the ACAdemic Curriculum}

From the students' perspective, there are four main reasons for taking part in the program during their studies: to enhance their academic program, to find a job after their studies, to improve their foreign language competences, and to acquire an international perspective and experience. All of these are related and help young graduates to enter the labor market. A study carried out among 240 outgoing students at the Universidad Autónoma de Madrid (with a response rate of 46 percent) found that 89 percent of the students surveyed assumed that having taken part in a mobility program would help them find a job in the future.

In many European universities, students are encouraged to complete part of their studies abroad. Under ERASMUS, students are exempt from paying fees at the host university and the credits they earn are recognized through a learning agreement signed by the student, the home university, and the host institution(s). The European Commission has set itself a target of 20 percent of mobile students by 2020 .

In Spain, as in other countries, ERASMUS mobility is not a "compulsory period abroad" in the academic curricula of most higher education institutions. Mobility windows as part of the curriculum are accessed predominantly on a voluntary basis and as a matter of student initiative, facilitated by the institution. Nevertheless, many students are keen to apply for a mobility program to enrich their CVs and to develop competences that will distinguish them from others.

\section{ERASMUS Mobility AND the EConomic Situation}

The latest statistics released by the European Commission on ERASMUS student mobility 20I2-2013 reveal that a new record has been achieved, with the program becoming more popular than ever. Moreover, this increasing trend in mobility numbers is seen both for study and internship

\section{More than 25 percent of Spanish are un- employed and 53.5 percent of Spaniards under age 25 have never worked.}

purposes, with internships now part of the program. Spain has maintained its leading position as the country that both receives and sends the highest number of ERASMUS students. In the academic year 20I2-20I3, 39,249 Spanish students joined the ERASMUS program. Although this is I percent less than the previous year, the data confirm that mobility is being consolidated in Spanish higher education institutions and is an implicit but important part of their curricula, notwithstanding the economic crisis.

Spain appears to be a country that attracts international talent to its universities, companies and institutions, as well as a country full of students keen to gain international experience and improve their CVs. The main concern now is not the students' desire to go abroad and explore new horizons, but the insufficient budget they receive to cover their living costs in the host country. This means that many Spanish families have to make significant financial efforts to cover the cost of the mobility period, in order to invest in their children's future.

Additionally, unemployment is one of the main worries of Spain's youth. The population of Spain is around 47 million inhabitants; but more than 25 percent are unemployed; 
and 53.5 percent of those under age 25 have never worked. From this point of view, it is not surprising that students are looking for education and work opportunities abroad that will help them find a job once back in Spain.

Even though the economy and the employment situation in Spain have not improved in the last few years, ERASMUS applications have remained stable or even grown. In other words, ERASMUS mobility has been consolidated as part of the Spanish curriculum despite economic difficulties and unemployment. These are the two key reasons that motivate Spanish students to join the ERASMUS program, whose main purpose is seen as a means to improve graduate employability.

\section{When is an International Branch Campus?}

\section{Nigel Healy}

Nigel Healey is professor and pro-vice-chancellor (International) at Nottingham Trent University, UK. E-mail:nigel.healey@ntu.ac.uk.

For or a Nottingham alumnus, driving onto the University - of Nottingham's branch campus in Malaysia is a surreal experience. Surrounded by tropical rainforest, a familiar white silhouette emerges - a clock tower atop the signature Trent Building, overlooking a large lake. Despite the heat and humidity, the campus at Semenyih looks and feels like an extension of the University of Nottingham, reinforcing its "one university, three campuses" (United Kingdom, Malaysia and China) branding.

\section{Defining International Branch Campuses}

In 2009, the Observatory for Borderless Higher Education (OBHE) famously defined an international branch campus as "an offshore operation of a higher education institution which meets the following criteria":

- "The unit should be operated by the institution or through a joint venture in which the institution is a partner...in the name of the foreign institution and

- upon successful completion of the course program, which is fully taken at the unit abroad, students are awarded a degree from the foreign institution."

This definition is widely cited and remains useful. Certainly, the Semenyih campus meets the criteria: the unit is operated as a joint venture between the University of Nottingham and two Malaysia property companies, Boustead and YTL; it is branded as University of Nottingham Malaysia Campus (UNMC); and the students graduate with a University of Nottingham degree.

OBHE's American counterpart, the Cross-Border Education Research Team (C-BERT) at the State University of New York at Albany, similarly defines an international branch campus as "an entity that is owned, at least in part, by a foreign education provider; operated in the name of the foreign education provider; engages in at least some faceto-face teaching; and provides access to an entire academic program that leads to a credential awarded by the foreign education provider."

\section{Changing Conditions and Environments}

A closer look at the 200 or so international branch campuses being monitored by the OBHE and C-BERT reveals that, as Jason Lane and Kevin Kinser noted in their cleverly titled article ("One definition to rule them all"), getting a clear definition "is a fairly slippery subject." In its 20 I2 report on international branch campuses, the OBHE acknowledged the impracticality of having a "permanent definition," because universities are constantly repositioning their offshore activities in the light of changing regulatory and competitive environments.

To illustrate the difficulty of defining an international branch campus, take the University of Nottingham's Malaysia Campus (UNMC) as an example. The "campus" is legally incorporated as a private Malaysian company, in which the two local partners have the majority stake. The University of Nottingham is, in effect, the minority shareholder in a private offshore company. With the exception of the senior managers, who are seconded from Nottingham, the faculty and staff are employed by the Malaysian company and managed by one of the Malaysian partner's human resources department on local terms and conditions.

UNMC is, from the perspective of the host Ministry of Education-a Malaysian private higher education institution. It is subject to oversight by the ministry, which approves its tuition fees and enrollments. Its curriculum is accredited by the Malaysian Qualifications Agency and the qualifications offered must fit within the Malaysian Qualifications Framework.

Viewed in terms of its key stakeholders, UNMC begins to look less like a UK transplant than the clock tower and the architecture of the buildings suggest. The majority shareholders are Malaysian. Most of the faculty and staff are Malaysian, and all but a handful of seconded managers are locally employed. The students, the regulators, and the companies that employ most of the graduates are all Malaysian. 